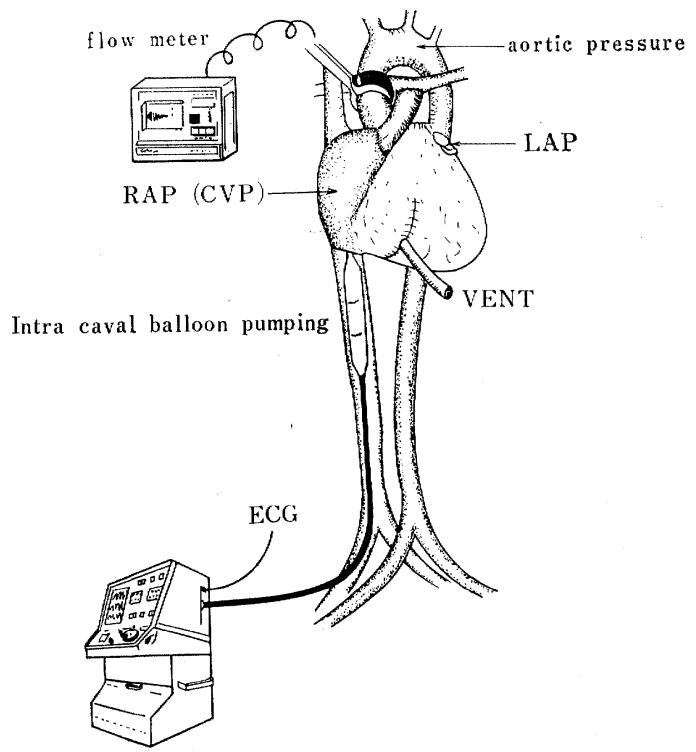

図 1 Hemodynamic effects of the balloon pumping after experimental Fontan operation

ようであるがわずかの実験例数であり，バルンの形状， 留置場所，パンピングのタイミング等とあわせ今後共検 討を加えていきたい. 下大静脈内でのパンピングや先天 性心疾患に対するパンピングはこれまで主に左心不全に 対する效果にのみ注目されて来たバルンパンピングの新

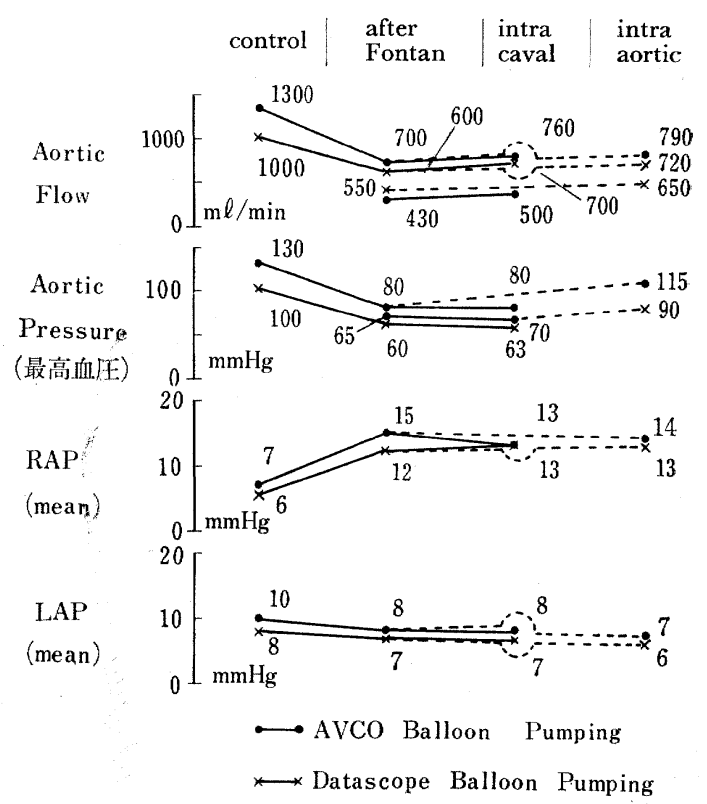

図 2 实験的Fontan 手術作製犬厄対与る balloon pumping の效果

しい適応分野と考える。な挍，Fontan 手術およびその 類似手術後の LOS に対し，IABP または ICBPを施 行し, 救命し得た症例および無效例を, 検討を加えてあ わせ報告した。

\title{
S-I-7 三尖弁閉鎖症に対する完全右心バイパス術
}

\section{東京女子矤科大学 日本心臟血圧研究所外科

橋本 明政 北村 信夫 遠藤 真彦 今井 康晴

林久恵 和田 寿郎

東京女子医大心研では 1956 年より 1979 年 1 月までに 98 例の三尖弁閉鎖症 (TA) に対し何らの手術が行われ た。それらの手術の大部分は Blalock-Taussig 吻合, Glenn 手術, ASD 挔大, 肺動脈 Banding 等であり, 1974 年より以後恃完全右心バイパス手術が加わり, 1979 年 1 月までに 10 例を数える.ここではこの完全右心バ イパス術施行の:10 例につき手術経験を述べる（表 1 ）.

これらの 10 例は 3 才から 19 才まで（平均 11.7 才） で男性 7 例, 女性 3 例, TA の型分類を Edwards-Burchell に従うと IB 型 8 例, IIB 型 2 例であった.
以前行われた手術と例数は Blalock-Taussig 吻合 5 例, Glenn 吻合 3 例で, Glenn 吻合の 1 例は Blalock 吻合後数震して行われたすのであったまな右心バイパ 又術の再手㣭が 1 例（第 1 例目）に行われた.

症例の選択に゙当っては, 現在年令的には 8〜9才以上 で体重が $30 \mathrm{~kg}$ を越える例が良いと考㝋て扣り, 術前 検査で IB，IIB 型が良く，肺動脈，肺血管床が良く発 達し, 左心機能が良好である必要がある，右房造影で下 大静脈认の逆流が軽度のものは, 右心バイパス術に当り 弁つきグラフトを要しないと考えている，またわれわれ 
表 110 cases of tricuspid atresia with right heart bypass

\begin{tabular}{|c|c|c|c|c|c|c|c|c|c|c|c|}
\hline $\begin{array}{r}\text { Case } \\
\text { No. }\end{array}$ & Name & $\begin{array}{l}\text { Age } \\
\text { yrs. }\end{array}$ & Sex & Type & $\begin{array}{l}\text { Previous } \\
\text { Surgery }\end{array}$ & $\begin{array}{l}\text { Operative } \\
\text { procedure }\end{array}$ & $\begin{array}{l}\text { Postop. } \\
\text { cyanosis }\end{array}$ & $\begin{array}{c}\text { Stay } \\
\text { in ICU }\end{array}$ & $\begin{array}{c}\text { CVP } \\
\text { in ICU }\end{array}$ & C. I. & Results \\
\hline 1 & & $3(4)$ & $\mathrm{M}$ & II - B & $(-)$ & RA-PA & $(-)$ & 10days & $25-20 \mathrm{~cm}$ & ${ }_{2} \mathrm{H}_{2} \mathrm{O}$ & Good for 4 years. \\
\hline 2 & & 16 & M & $\mathrm{I}-\mathrm{B}$ & Glenn & $\mathrm{RA}-\mathrm{RV}$ & $(+)$ & 15 & $27-21$ & & Good for 4 Y. $5 \mathrm{mo}$ \\
\hline 3 & & 10 & $\mathrm{~F}$ & $I-B$ & Blalock & $\mathrm{RA}-\mathrm{RV}$ & $(-)$ & 6 & $22-20$ & & Good for $3 \mathrm{y} .6 \mathrm{mo}$ \\
\hline 4 & & 13 & $\mathrm{~F}$ & $\mathrm{I}-\mathrm{B}$ & Glenn & $\mathrm{RA}-\mathrm{RV}$ & $(-)$ & 6 & $23-20$ & & Good for $3 \mathrm{y} .4 \mathrm{mo}$. \\
\hline 5 & & 15 & $\mathrm{M}$ & $\mathrm{I}-\mathrm{B}$ & $\begin{array}{l}\text { Blalock } \\
\text { \& Glenn }\end{array}$ & RA-RV & $(+)$ & 4 & $13-12$ & & Poor (ASD open) \\
\hline 6 & & 8 & $\mathrm{~F}$ & $I-B$ & $(-)$ & $\mathrm{RA}-\mathrm{RV}$ & $(-)$ & 9 & $25-20$ & & Good for 2 y. $6 \mathrm{mo}$ \\
\hline 7 & & 10 & M & $I-B$ & Blalock & RA-PA & $(-)$ & 7 & $25-20$ & 2. 30 & Good for $1 \mathrm{y} .3 \mathrm{mo}$. \\
\hline 8 & & 7 & M & III -B & $(-)$ & RA-RPA & $(-)$ & 6 & $23-21$ & & Good for $8 \mathrm{mo}$ \\
\hline 9 & & 19 & M & $I-B$ & Blalock & $\mathrm{RA}-\mathrm{RV}$ & $(-)$ & 5 & $24-20$ & 1.90 & Good for 6 mo. \\
\hline 10 & & 16 & $\mathrm{M}$ & $\mathrm{I}-\mathrm{B}$ & Blalock & $\mathrm{RA}-\mathrm{RV}$ & $(-)$ & 4 & $24-20$ & 2. 28 & Good for 4 mo. \\
\hline
\end{tabular}

の経験からも Glenn 手術後の右心バイパス症例ではチ アノ一ゼが残存することがあり，Glenn 術後右房発達も 期待できず，一方，Blalock-Taussig 吻合後には肺血管 床や左心機能の発達と共に右房機能も良好ならしめるの で，幼少時の姑息的手術としては Blalock 吻合がよい と考完る.

手術方法は右房機能温存の意味から体外循環 用の cannulation を上大静脈および大腿静脈（あるいは下大 静脈近くの右房) から行い, 右心耳を切開して ASD を パッチ閉鎖し，IB 型では右心耳と右室流出路または主 肺動脈間に通常代用弁のつかない代用血管に短絡を作成 し, IIB 型では通常右心耳と肺動脈（特に右側）の間に 短絡形成を行 5 。術後 ICU 管理は CVP をやや高め にして血圧を維持する.

ここで症例 1 から手術経験をふりかえってみると（図 1), 症例 1 は IIB 型でこの症例のみは 3 才と低年令で あったが，始め右房肺動脈間に異種生体弁つき代用血管 による短絡形成を行ったが，異種生体弁括よび肺動脈吻 合部との狭窄を来し， 8 力月後に弁つきグラフトを取り はずして主肺動脈分岐部と右房とを直接吻合して後壁を 作成し，心膜パッチにて前壁を作成して短絡を完成し た. 術後心カテーテル検查で上下大静脈と右房の圧上昇 を認めるが，チアノーゼは消失し運動量も著明に増加し た. この症例以後は通常代用弁を用いない単純な右心バ れパス作成にて可能と考光た. 症例 2 は 16 才男性の IB 型で, 5 执でlenn 手術を5けているが，肺動脈 弁の発達が良好なので右心耳と右室流出路間に代用血管 による短絡作成を行った。この方法も可能な場合は以後 の手術方法となった。 術後はチアノーゼが軽度に 残存 し, 以前行われた Glenn 手術の影響と考学られた。
症例 3, 4, 5 は IB 型で, 右心耳一右室流出路間に 代用血管による短絡作成を行ったが，症例 5 のみは ASD の直接綘合閉鎖を行って術後 ASD 再開通を来し, チアノーゼがみられる.

症例 6 と 10 は IB 型で右心耳一右室流出量間に症例 7 は IB 型で右心耳一主肺動脈間に代用血管による短絡 を作成し, 症例 8 は IIB 型で右心耳と右肺動脈間の直 接吻合, 症例 9 は IB 型で右心耳と右室流出路を直接吻 合した，術後右心内圧はいずれす上昇を示した。

術後 ICU にては, CVPを $20 \sim 25 \mathrm{mmH}_{2} \mathrm{O}$ に保ち, DOA あるいは isoproterenol の少量を使用してほぼ 1 週間前後で ICU より帰室できたが，ICU 滞在期間お よび血行動態管理も, 初期の症例に比べ最近の症例では 管理が容易になり，ICU 滞在期間も短縮しつつある傾 向がみられる. 術後心係数は $1.9 \sim 2.3 \mathrm{l} / \mathrm{min} / \mathrm{m}^{2}$ とやや 低值を示していた，今後の再検を要する.

術後遠隔成績は最長 4 年 5 力月から 4 力月にわたり全 例生存している. 以前 Glenn 手術をうけた 3 例中 2 例 がチアノーゼを示すが，らち1例は ASD 再開通によ る. Glenn 手術は遠隔期に肺内短絡を来すと報告され， 前述の理由からも TA に対してはさけた方がよい， ASD 再開通の 1 例を除き 9 例はいずれる運動量が著明 に増加し, 強心剤, 利尿剂も不要である.

以上 TA に対する完全右心バイパス術 10 例の経験を 述べたが，この手術は一応機能的根治術といわれ，われ われは代用弁を用いずに短絡作成を行って最長 4 年 5 力 月までは良好にみえる。しかし術後予後には問題を残し ている.すすおち患児の身体発育に伴い短絡が相対的に 狭小化してこないか，また術前後の右心内压曲線で高い 右房 $a$ 波がみられるが，心房細動発生後はどのような 
図 110 cases of tricuspid atresia with right heart bypass (I)

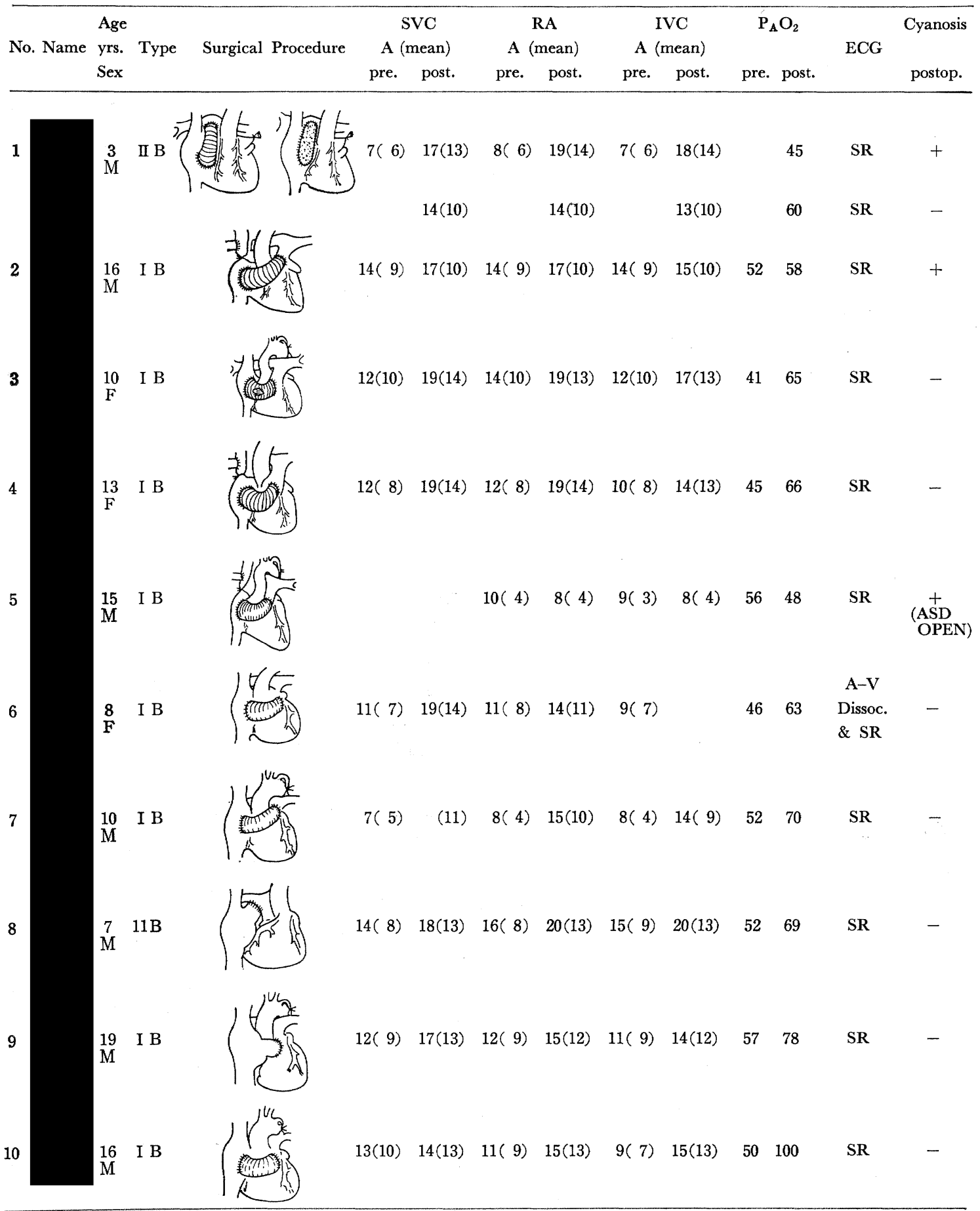

